\title{
Small mammals from barn owl Tyto alba pellets in a Mediterranean agroforestry landscape of central Italy
}

\author{
Vincenzo Ferri ${ }^{1}$, Paolo Crescia ${ }^{1}$, Stefano Celletti ${ }^{1}$, Christiana Soccini ${ }^{1}$, \\ Corrado Battisti2*
}

\begin{abstract}
In order to investigate diversity patterns and similarities in the small mammal communities of an agroforestry landscape in western central Italy (Maremma of Lazio), we analyzed, in a multivariate setting (Cluster analysis, DCA-Detrended Correspondence Analysis), the prey content of barn owl Tyto alba pellets collected along one year in five sampling sites. Small mammal communities were composed by guilds typical of habitats included in agroforestry landscapes (croplands and mosaics, forests and ecotones, wet habitats and synanthropic ones). Since landscape matrices were characterized almost everywhere by croplands, typical agro-ecosystem species (Apodemus cfr. sylvaticus, Microtus savii, Mus domesticus and Soricidae) dominated in the majority of the collecting sites. The statistical analyses show how small changes in land use and cover can explain the faunal differences between sites, with the occasional presence of Arvicola italicus in wet habitats, and of Muscardinus avellanarius and Sorex samniticus in sites dominated by forest or agroforestry ecotones.

Communities recorded in sites characterized by wet and forest habitats showed a higher distance from the others, dominated by croplands. Communities occurring in landscapes with the lowest habitat diversity showed also the lowest species diversity.
\end{abstract}

Key words: Agroforestry landscapes, equitability, habitat diversity, species diversity, species richness.

Riassunto - Piccoli mammiferi da borre di barbagianni (Tyto alba) in un paesaggio agroforestale mediterraneo dell'Italia centrale.

Per indagare $\mathrm{i}$ pattern di diversità e di somiglianza nelle piccole comunità di mammiferi di un paesaggio agroforestale dell'Italia centrooccidentale (Maremma del Lazio), abbiamo analizzato, in un contesto di analisi multivariata (Cluster analysis, DCA-Detrended Correspondence analysis), il contenuto di prede in borre di barbagianni Tyto alba raccolte durante un anno in cinque siti di campionamento.

Le comunità di piccoli mammiferi erano composte da gilde tipiche degli ambienti compresi nei paesaggi agroforestali (terreni colti-

${ }^{1}$ GNML Gruppo Naturalistico della Maremma Laziale, vicolo della Petrara, 4, 01016 Tarquinia, Italia.

E-mail: associazione.gnml@gmail.com

2 "Torre Flavia" Long Term Ecological Research (LTER) Station, Città Metropolitana di Roma, via Ribotta, 41, 00143 Roma, Italia.

*Correspondingauthor:c.battisti@cittametropolitanaroma.gov.it

(C) 2021 Vincenzo Ferri, Paolo Crescia, Stefano Celletti, Christiana Soccini, Corrado Battisti

Received for publication: 6 January 2021

Accepted for publication: 7 July 2021

Online publication: 29 October 2021 vati e mosaici, foreste ed ecotoni, zone umide e habitat sinantropici). Poiché le matrici paesaggistiche erano caratterizzate quasi ovunque da terreni coltivati, le specie tipiche dell'agroecosistema (Apodemus cfr. sylvaticus, Microtus savii, Mus domesticus e Soricidae) dominano nella maggior parte dei siti di raccolta. Le analisi statistiche evidenziano come piccoli cambiamenti nella copertura o nell'uso del suolo possono spiegare le differenze faunistiche tra siti, con Arvicola italicus occasionalmente presente negli ambienti umidi e Muscardinus avellanarius e Sorex samniticus nei siti dominati dalla foresta o negli ecotoni agro-forestali. I siti con la più bassa eterogeneità ambientale (=diversità di habitat) hanno mostrato anche la più bassa diversità di specie. La composizione e la dominanza di specifiche tipologie d'uso/copertura del suolo nelle aree limitrofe ai siti di campionamento spiegano le somiglianze tra le comunità di piccoli mammiferi. In particolare, due siti (uno inserito in un paesaggio a matrice forestale dominante, l'altro caratterizzato da bassa diversità ambientale) hanno evidenziato una maggiore dissimilarità strutturale dagli altri.

Parole chiave: Diversità ambientale, diversità di specie, equiripartizione, paesaggio agroforestale, ricchezza di specie.

\section{INTRODUCTION}

Worldwide, communities of small mammals are indirectly studied using owl's (Aves: Strigiformes) pellets including remnants (mainly skulls and jaws) of these preys (e.g., Contoli \& Sammuri, 1978; Bonvicino \& Bezerra, 2003). Using this technique, a large amount of data is quickly available, although some limitation of this approach has been highlighted (Yom-Tov \& Wool, 1997; Andrade et al., 2016). For example, since some owl species are stenoecious, inhabiting only specific habitats (as in the case of barn owl Tyto alba foraging mainly in open-mosaic landscapes; Martínez \& Zuberogoitia, 2004), information about small mammal assemblages may be obtained only for these contexts. Moreover, this type of sampling is highly opportunistic since it was indirectly obtained from the predators, therefore not following a standardized sampling protocol). However, excluding some weaknesses, there are many points of strength in this technique (Andrade et al., 2016): for example, once selected a roosting or nesting barn owl site, we can obtain representative samples with a low research effort and, consequently, we may obtain a large set of data about prey species and their frequencies, richness, diversity, and other univariate metrics. Other methods (e.g. capture-mark-recapture by trapping) allow to obtain fewer representative samples (often with a high research effort) and diversity metrics 
at community level are more difficult to achieve (Heisler et al., 2016). Data on small mammal communities, obtained from owl' pellets, may be also useful to assess change in local owl diets (e.g. Catalisano \& Massa, 1987; Love et al., 2000; Veselovský et al., 2017), composition, diversity and temporal trends in prey assemblages (e.g., Clark \& Bunck, 1991; Bonvicino et al., 2003; Avenant, 2005; Celauro \& Battisti, 2006; Meek et al., 2012; Stefke \& Landler, 2020), multi-level trophic systems (e.g., Contoli, 1986; Contoli et al., 2002), ecological value and environmental quality at different spatial/temporal scales (e.g., Prete et al., 2012; Torre et al., 2015; Mancini et al., 2019), until to altitudinal (e.g. Milana et al., 2019), latitudinal (e.g. Leveau et al., 2006), biogeographical (e.g., Contoli et al., 1987; Battisti et al., 1997, 2019, 2020a) and genetic analyses (e.g. Taberlet \& Fumagalli, 1996). Finally, also information about the presence or absence of specific, cryptic or threatened taxa can be obtained using this approach (e.g., Contoli, 1986; Contoli et al., 1992; McDonald et al., 2014; Biedma et al., 2019; Kiamos et al., 2019; Battisti et al., 2020b).

Among the Strigiformes, the barn owl is widely used as source of data. Barn owls may be selective in habitat use, but are described by many as opportunistic predators that do not exhibit any food preferences; therefore, the species present in their pellets should provide a quite accurate representation of local prey abundance or accessibility (Taylor, 1994; Salvati et al., 2002; Heisler et al., 2016).

Generally, the foraging habitat of barn owls is represented by open landscapes, including grasslands, orchards, newly planted coniferous plantations and recently felled woodlands (Taylor, 1994). The unmanaged grassland edges provided by agricultural crops, woodland ecotones, riverbanks, ditches and hedgerows also have value in more intensively managed landscapes (Salvati et al., 2002). In the wild, barn owls are generally sedentary. Nests are abandoned only if the surrounding habitat becomes devoid of prey, due to changes in habitat quality and structure, or if the nests or roosts are altered (Taylor, 1994). Therefore, a good knowledge of the species' feeding habitat and nesting/roosting sites allows to rapidly collect a large number of pellets containing a significant representation of their small-mammal preys (Contoli, 1975).

In this work, by using barn owls' pellets, we collected data about the small mammal guilds living in five sites located in an agroforestry landscape of Tyrrhenian central Italy (Maremma of Lazio). With the statistical analysis of these data, we aim to obtain an arrangement of small mammal frequency, richness, equitability and diversity, also in relation with the local landscape features and heterogeneity (habitat diversity).

\section{MATERIALS AND METHODS}

\section{Study area and sample collection}

We carried out a broad-scale sampling of barn owl pellets (summer 2018-summer 2019), in five collection sites distributed throughout the Tyrrhenian territory of the province of Viterbo, in habitats referable to the Maremma of Lazio (Fig. 1), the southernmost part of the Maremma, a region situated across the border between southern Tu-

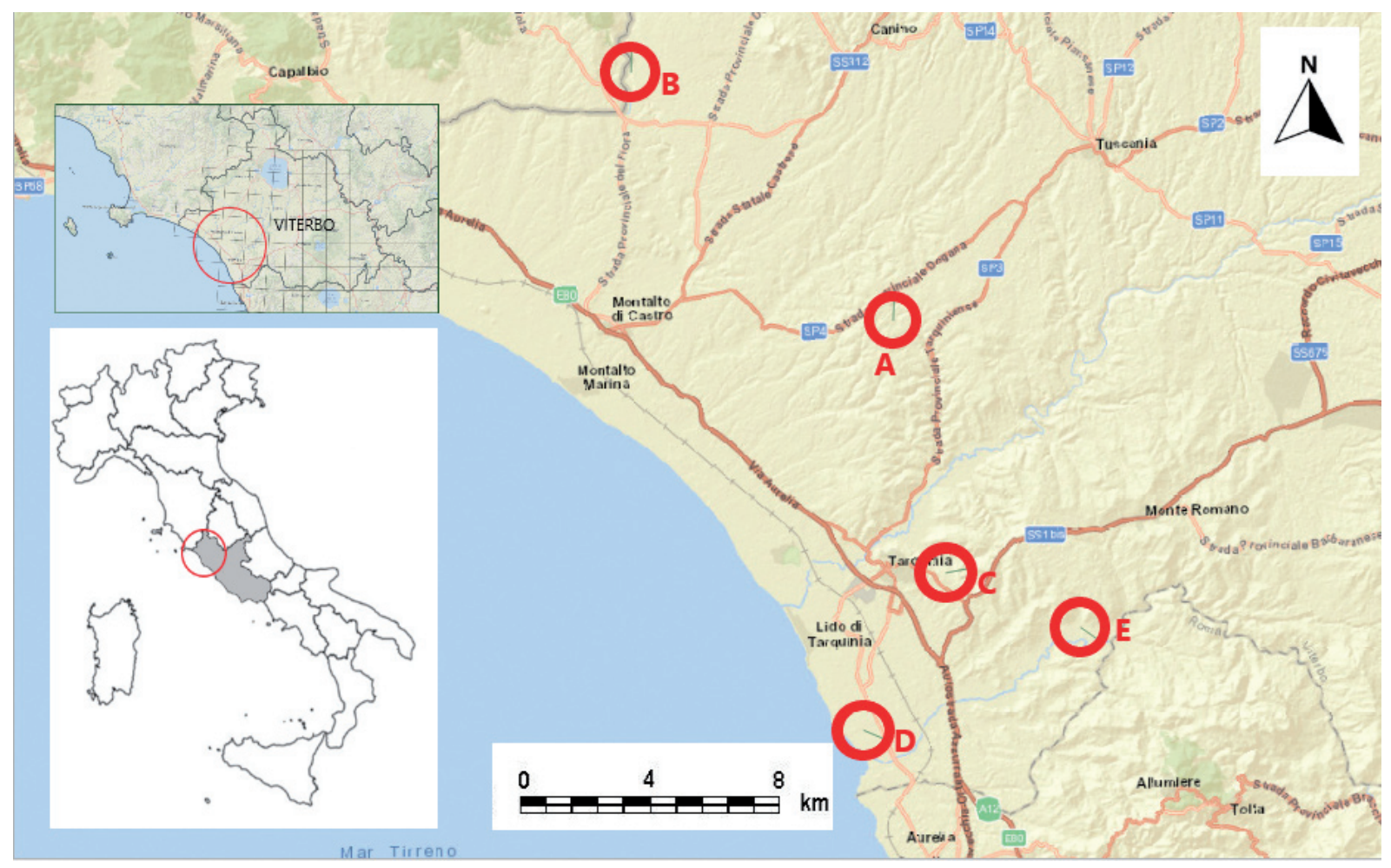

Fig. 1 - The study area. Circles and letters (A-E) show the five investigated sites. / Area di studio. I cerchi e le lettere (A-E) indicano i cinque siti studiati. 
scany and northern Lazio, in central Italy. The study area includes the Tyrrhenian coastal strip and the corresponding plain delimited to the north-west by the final course of the Chiarone River, which marks the border between the Maremma di Grosseto, in Tuscany, and Tuscia, in Lazio (Olmi \& Zapparoli, 1992), and to the south, up to Cerveteri, by the headland of Capo Linaro which represents the southernmost offshoot of the Tolfa Mountains (De Zuliani, 2011). The area was described as a transitional zone from a Mediterranean to a Temperate bioclimate (Blasi, 1994) and has distinctive geological and vegetation features (Marchetti et al., 2014; Cutini et al., 2010).

\section{Sampling sites}

Nest Site A. Roccaccia ( $42^{\circ} 21^{\prime} 0.50^{\prime \prime} \mathrm{N} ; 1^{\circ} 45^{\prime} 31.75^{\prime \prime}$ $\mathrm{E} ; 149 \mathrm{~m}$ a.s.1.). The area is characterized by fodder crops, interspersed with coppices, composed of mixed Mediterranean oaks dominated by Turkey oaks Quercus cerris and downy oaks Quercus pubescens. Some sectors have been reforested with coniferous species (Pinus spp. and Cupressus spp.). Both cultivated areas and coppices are used in rotation or seasonally as a pasture for free-ranging cattle.

Nest Site B. Riminino (42²7'10.57' N; 11'37'9.57' E; $90 \mathrm{~m}$ a.s.1.). The area is characterized by a limestone escarpment irregularly covered by Mediterranean arboreal and shrub vegetation, overlooking a large grassy plain grazed by free-ranging cattle. The plain is crossed by the Fiora River, with hygrophilous vegetation growing along the banks. Above the escarpment there are plots bounded by hedges and crossed by ditches edged by hygrophilous vegetation, which are cultivated with fodder and cereals and successively used as pastures for sheep or as olive groves.

Nest Site C. Ripagretta ( $42^{\circ} 14^{\prime} 50.82^{\prime \prime}$ N; $11^{\circ} 47^{\prime} 4.60$ ” E; $122 \mathrm{~m}$ a.s.l.). The site is characterized by slightly elevated limestone cliffs, partly covered by Mediterranean vegetation with prevalent arboreal and shrubby holm oak Quercus ilex and some downy oaks. The cliffs overlook a valley with vineyards, pastures and grasslands, with hedges and ecotonal habitats. In the above plateau, the westernmost sector is urbanized, while the rest is occupied by the Necropolis of Tarquinia, where the prevailing herbaceous cover is periodically mown, and by cereal crops.
Nest Site D. San Giorgio (42¹1'4.00” N; 11 ${ }^{\circ} 44^{\prime} 17.75^{\prime \prime}$ E; $6 \mathrm{~m}$ a.s.1.). Mosaic of croplands (mainly forage, cereal or horticultural crops), interspersed with uncultivated areas and sheep pastures. There are isolated oaks Quercus spp., hedges, reservoirs and drainage channels with hygrophilous and riparian vegetation, as well as a pine Pinus sp. and Italian stone pine $P$. pinea forest.

Nest Site E. Montericcio (42 13 '26.52” N; $11^{\circ} 51^{\prime 2} 24.96^{\prime \prime} \mathrm{E} ; 26 \mathrm{~m}$ a.s.l.) Not far from the Mignone River, the area is mainly characterized by herbaceous (cereals) and horticultural crops, which are used in succession as sheep pastures. There are slopes with Mediterranean and sub-Mediterranean arboreal and shrubby vegetation, hedges and tree-lined rows and drainage channels with associated hygrophilous vegetation.

The landscape composition was assessed using Google Earth ${ }^{\circledR}$ (last accessed: October 2020) and landscape elements were analysed in detail within a $1 \mathrm{~km}$ radius area around each nest site, which approximates to the home range size $\left(3 \mathrm{~km}^{2}\right)$ of a barn owl during the breeding season (Taylor, 1994; Horvàth et al., 2018). The five nest sites were described based on land-use types and the percentages for the following categories calculated: 1) agricultural fields (annual and perennial crops); 2) extensive land use (grasslands, pastures, orchards, vineyards); 3) wet habitats (including river banks, streams, artificial lakes, etc.); 4) forests (all forest habitats), and 5) urbanized areas (Tab. 1).

\section{Pellet analysis}

Pellets were collected from the nest sites between July 2018 and September 2019. Pellets were processed using the dry technique, with single pellets disassembled by hand and the prey items identified at the lowest possible taxonomic level.

Osteological parts (mainly skulls and jaws) were macroscopically identified, while teeth and feathers were identified under a stereo microscope at $25 \times$ or $50 \times$ magnifications. Analyses have been carried out in a private laboratory. The identification was carried out at the species level, where possible, by comparing undigested remains with a reference collection (see Contoli, 1980) and following Amori et al. (2008).

Prey numbers were estimated as the minimum number of individuals (MNI) obtained by counting the most

Tab. 1 - Percentages of land use/cover and habitat diversity index (Hh) in the five studied sites. / Percentuali di uso/copertura del suolo e diversità ambientale $(\mathrm{Hh})$ nei cinque siti studiati.

\begin{tabular}{|l|c|c|c|c|c|}
\hline & Roccaccia (A) & Riminino (B) & Ripagretta (C) & San Giorgio (D) & Montericcio (E) \\
\hline Cropland & 8.53 & 87.62 & 96.4 & 94.71 & 93.61 \\
\hline Orchards and vineyards & 0.1 & 2.64 & 0.02 & 0 & 0.6 \\
\hline Wet habitats & 0.77 & 8.03 & 0.45 & 2.3 & 1.35 \\
\hline Forests and wood mosaics & 90.54 & 1.14 & 1.2 & 0.78 & 4.03 \\
\hline Urbanized areas & 0.06 & 0.57 & 1.93 & 2.21 & 0.41 \\
\hline Hh index & 0.349 & 0.495 & 0.191 & 0.26 & 0.303 \\
\hline
\end{tabular}


common diagnostic osteological element of each species of small mammal in each pellet (McDowell \& Medlin, 2009).

Nomenclature followed Loy et al. (2019). Since the determination of the remnants of Apodemus to the species level is difficult for this genus in Italy, we used Apodemus cfr. sylvaticus for the individuals assigned to this taxon.

The number of pellets collected from each site varied considerably, but cumulative occurrence plots demonstrated that collections $>10$ pellets were adequate to assess the main species present in the diet (Bond et al., 2004).

For each site, we obtained the number of species (S) and the normalized species richness (Margalef index) as $\mathrm{Dm}=(\mathrm{S}-1) / \ln (\mathrm{N}-1)$ (Margalef, 1958), where $\mathrm{N}$ was the total number of prey items. For each site we obtained the relative frequency of each species from the number of individuals ( $\mathrm{fr}_{\mathrm{i}}$, as number of ind. of the $\mathrm{i}$-th species/total number of individuals). Finally, we obtained two univariate metrics of diversity: the Shannon-Wiener diversity index (Shannon \& Weaver, 1949), as $\mathrm{H}^{\prime}=-\Sigma \mathrm{fr}_{i} \times \operatorname{lnfr}_{i}$ and the equitability index, as $\mathrm{e}=\mathrm{H}^{\prime} / \mathrm{H}^{\prime}{ }_{\text {max }}$ where $\mathrm{H}^{1}{ }_{\text {max }}=\ln (\mathrm{S})$ (Pielou, 1966; details in Magurran, 2004). To assess the level of environmental heterogeneity $(\mathrm{Hh})$, in each site we calculated an index of habitat diversity, following the analogous Shannon-Wiener formula.

We compared H' to Hh using the non-parametric Spearman rank correlation test (2 tail).

From a species/site matrix, we performed both a Cluster analysis (Algorithm: Paired group - UPGMA, Euclidean similarity index) obtaining a dendrogram, in order to assess the similarity among communities, and a Detrended Correspondence Analysis (DCA) in order to test for the linkage among sites (i.e. assemblages) and species (Hill \& Gauch, 1980).

For statistical analyses we used the computer software PAST 4.01 (Hammer et al., 2001). The statistical tests were considered significant at the alpha level of 0.05 as standard in all analyses (Dytham, 2011).

\section{RESULTS}

Totally, we examined 373 pellets, identifying 687 remnants belonging to 11 terrestrial small mammal species: Apodemus cfr. sylvaticus (39\%), Microtus savii (19.5\%), Mus musculus (15.3\%), Crocidura suaveolens (7.9\%), Crocidura leucodon (7.4\%) and Suncus etruscus (5.1\%) being dominant (total frequency $>5 \%$ ) on the whole (Tab. 2). Arvicola italicus is the only species of conservation concern at national scale (Near Threatened; Rondinini et al., 2013). We obtained also data on bats (Chiroptera: Pipistrellus sp., Eptesicus serotinus), and on other taxonomic groups (birds: Passer italiae, and undetermined beetles), not included in the analyses.

The sites of Riminino (B), San Giorgio (D) and Monte Riccio (E) showed the highest Shannon-diversity and equitability indices, while Ripagretta (C) showed the lowest values. San Giorgio showed also the highest normalized species richness (Tab. 3). Species diversity H' was not significantly correlated directly to habitat diversity $\mathrm{Hh}\left(\mathrm{r}_{\mathrm{s}}=0.743, \mathrm{p}=0.20\right.$; Spearman rank correlation test, 2 tail).

Dendrogram indicated two similarity groups: the less diversified A-C vs. other sites (correlation: 0.9851; Fig. 2). Detrended Correspondence Analysis (DCA; Eigenvalue: axis 1: 0.1675, axis 2: 0.060; Fig. 3) displayed an analogous pattern, highlighting the general similarities and showing the faunal peculiarity of two sites (Riminino - B, the only site with Arvicola italicus, and San Giorgio - D, with the only record of Rattus norvegicus) and the low evenness and diversity of the sites A (Roccaccia) and C (Ripagretta) with a high concentration of dominance (frequency) of synanthropic species (Apodemus cfr. sylvaticus and Mus musculus).

Tab. 2 - Small mammal species, number of records (n) and relative frequency ( $\mathrm{fr}_{\mathrm{i}}$ ) in the five studied sites. / Specie di piccoli mammiferi, numero di reperti (n) e frequenza relativa $\left(\mathrm{fr}_{\mathrm{i}}\right.$ ) nei cinque siti studiati.

\begin{tabular}{|c|c|c|c|c|c|c|c|c|c|c|c|c|}
\hline \multirow[b]{2}{*}{ Species } & \multicolumn{2}{|c|}{$\begin{array}{l}\text { Roccaccia } \\
\text { (A) }\end{array}$} & \multicolumn{2}{|c|}{$\begin{array}{l}\text { Riminino } \\
\text { (B) }\end{array}$} & \multicolumn{2}{|c|}{$\begin{array}{l}\text { Ripagretta } \\
\text { (C) }\end{array}$} & \multicolumn{2}{|c|}{$\begin{array}{l}\text { San Giorgio } \\
\text { (D) }\end{array}$} & \multicolumn{2}{|c|}{$\begin{array}{c}\text { Montericcio } \\
\text { (E) }\end{array}$} & \multicolumn{2}{|c|}{ Total } \\
\hline & $\mathrm{n}$ & $\mathrm{fr}_{\mathrm{i}}$ & $\mathrm{N}$ & $\mathrm{fr}_{\mathrm{i}}$ & $\mathrm{n}$ & $\mathrm{fr}_{\mathrm{i}}$ & $\mathrm{n}$ & $\mathrm{fr}_{\mathrm{i}}$ & $\mathrm{N}$ & $\mathrm{fr}_{\mathrm{i}}$ & $\mathrm{n}$ & $\mathrm{fr}_{\mathrm{i}}$ \\
\hline Sorex samniticus Altobello, 1926 & 4 & 0.024 & 0 & 0 & 3 & 0.030 & 0 & 0 & 3 & 0.018 & 10 & 0.015 \\
\hline Crocidura suaveolens (Pallas, 1811) & 9 & 0.054 & 26 & 0.123 & 6 & 0.059 & 4 & 0.111 & 9 & 0.053 & 54 & 0.079 \\
\hline Arvicola italicus Savi, 1839 & 0 & 0 & 6 & 0.028 & 0 & 0 & 0 & 0 & 0 & 0 & 6 & 0.009 \\
\hline Microtus savii (de Sélys Longchamps, 1838) & 7 & 0.042 & 75 & 0.355 & 4 & 0.040 & 4 & 0.111 & 44 & 0.257 & 134 & 0.195 \\
\hline Apodemus cfr. sylvaticus (Linnaeus, 1758) & 86 & 0.512 & 54 & 0.256 & 66 & 0.653 & 12 & 0.333 & 50 & 0.292 & 268 & 0.390 \\
\hline Mus domesticus Schwarz and Schwarz, 1943 & 35 & 0.208 & 25 & 0.118 & 10 & 0.099 & 9 & 0.250 & 26 & 0.152 & 105 & 0.153 \\
\hline
\end{tabular}




\section{DISCUSSION}

The study revealed small mammal communities composed by typical species of the agroforestry landscapes of central Italy (e.g. Contoli, 1986; Aloise et al., 1990; Capizzi \& Luiselli, 1998; Battisti et al., 2019) that host different ecological guilds, as species strictly linked to croplands and mosaics (e.g. Microtus savii, Apodemus cfr. sylvaticus and Soricidae), to forests and ecotones ( $\mathrm{Mu}$ scardinus avellanarius, Sorex samniticus), to wet habitats (Arvicola italicus) and finally, synanthropic rodents (Mus domesticus, Rattus spp.).

Tab. 3 - Number of pellets (N pel), number of records (n), number of species (S), Shannon-Wiener diversity index (H'), equitability (e), normalized richness (Margalef index, $\mathrm{Dm})$. / Numero di borre $(\mathrm{N}$ pel), numero di reperti (n), numero di specie (S), indice di diversità di ShannonWiener (H'), equiripartizione (e), ricchezza normalizzata (indice di Margalef, Dm).

\begin{tabular}{|l|c|c|c|c|c|c|}
\hline Site & N pel & $\mathrm{n}$ & $\mathrm{S}$ & $\mathrm{H}^{\prime}$ & $\mathrm{e}$ & $\mathrm{Dm}$ \\
\hline Roccaccia (A) & 88 & 168 & 9 & 1.533 & 0.698 & 1.561 \\
\hline Riminino (B) & 92 & 211 & 8 & 1.686 & 0.811 & 1.308 \\
\hline Ripagretta (C) & 46 & 101 & 9 & 1.294 & 0.589 & 1.733 \\
\hline San Giorgio (D) & 20 & 36 & 7 & 1.715 & 0.881 & 1.674 \\
\hline Montericcio (E) & 127 & 171 & 9 & 1.798 & 0.818 & 1.556 \\
\hline
\end{tabular}

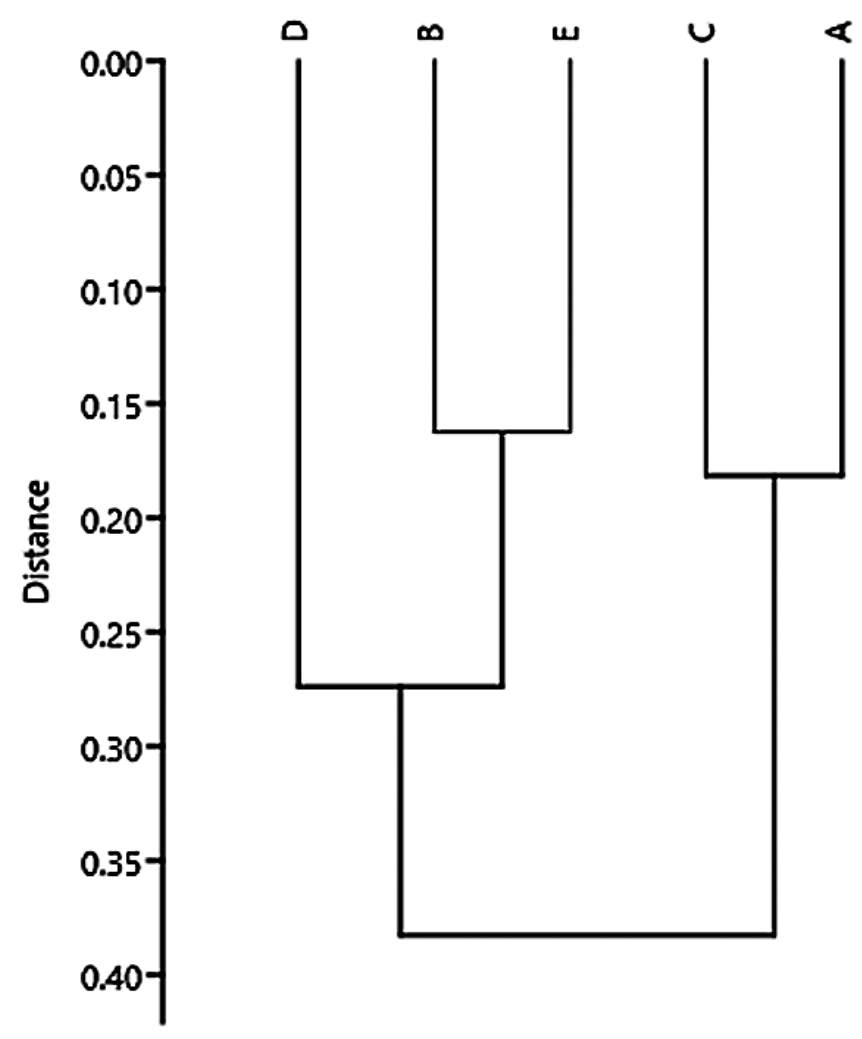

Fig. 2 - Dendrogram of similarity based on species frequency (algorithm: Paired group - UPGMA, Euclidean similarity index). / Dendrogramma di similarità basato sulla frequenza di specie (algoritmo: gruppi appaiati - UPGMA, indice di similarità euclidea). Sites: / Siti: A) Roccaccia. B) Riminino. C) Ripagretta. D) San Giorgio. E) Montericcio.

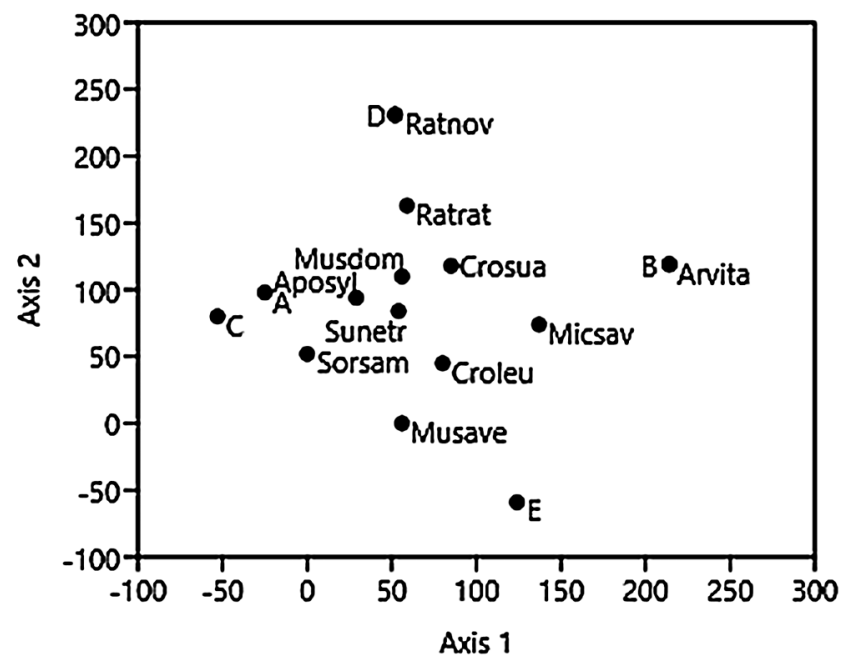

Fig. 3 - Detrended Correspondence Analysis. / Analisi delle Corrispondenze 'Detrended' Sites: / Siti: A) Roccaccia; B) Riminino; C) Ripagretta; D) San Giorgio; E) Montericcio. Species: / Specie: Sunetr: Suncus etruscus; Sorsam: Sorex samniticus; Crosua: Crocidura suaveolens; Croleu: Crocidura leucodon; Musave: Muscardinus avellanarius; Arvita: Arvicola italicus; Micsav: Microtus savii; Aposyl: Apodemus cfr. sylvaticus; Musdom: Mus domesticus; Ratrat: Rattus rattus; Ratnor: Rattus norvegicus.

Except for site A (Roccaccia), all the other sites are characterized by landscape matrices with dominance of extensive croplands and other open habitats. These features explain the almost general predominance of species linked to these environments. However, minor changes among sites about land cover and its use can explain the different faunal composition. Muscardinus avellanarius and Sorex saminiticus (forest and ecotone species) have been recorded in the site with higher forest cover (Roccaccia - A and, secondarily, Ripagretta - C and Montericcio - E). Moreover, in the site A forest-dominated the frequency of Microtus savii, a species linked to open agro-mosaic (Caroli et al., 2000), is lowest than other sites. The localized presence of wet habitats (near the site B - Riminino) explains the occurrence of Arvicola italicus and the dissimilarity from the sites A (Roccaccia) and C (Ripagretta). These last sites showed a high similarity. This pattern could be assigned to a low evenness of both of them that, although different in land use cover, showed communities with a very high concentration of dominance in only two synanthropic species (Apodemus cfr. sylvaticus and Mus musculus) and the lower frequencies of in Microtus savii.

The limited number of sites and the different level of anthropization did not allow to obtain a significant correlation between habitat diversity index (a proxy of landscape heterogeneity) and species diversity. However, excluding the site D having a low prey sample, the sites with lowest habitat diversity also showed the lowest species diversity. The less environmental diversified site (Ripagretta - C) showed the lowest species diversity index and equitability.

Land use composition and habitat diversity can explain species frequency similarities among small mammal communities. In this regard, two sites (A and C) showed 
a higher distance from the others. The first is included inside a forest-dominated landscape and the second is the less environmentally diversified. This finding would corroborate what stated by Varuzza et al., (2001), which evidenced differences in prey diversity between sites located in forest $v s$. cultivated sites. This pattern of similarity is confirmed by DCA analysis, which highlights the faunal distinctiveness of sites $\mathrm{B}$ and $\mathrm{D}$, the low diversity and uniformity of sites A and C, and suggests the existence of a relationship between species and sites. In this regard, axis 1 can represent the diversity/uniformity pattern. However, the same axis shows a low amount of overall information (eigenvalue about 17\%) and the relative frequency of individual species may likely influence the observed pattern.

Data from owl's pellets provide a large amount of faunal, ecological and biogeographical information at site- and landscape-levels allowing in-depth analyses on diversity metrics of small mammal assemblages with a limited field effort. In this regard we would stimulate further research.

\section{Acknowledgements}

We thank Giovanni Amori, Longino Contoli and Spartaco Gippoliti which gave useful hints on a first draft of the manuscript. Two anonymous reviewers and the Editor (Giorgio Chiozzi) provided valuable comments and suggestions at the same time improving the style and language of the manuscript.

\section{REFERENCES}

Aloise G., Pelosi M. \& Ronca M., 1990 - Small mammal communities of the "Monte Rufeno" Natural Reserve (Latium, Italy): data from Barn Owl Tyto alba pellets. / I popolamenti di micromammiferi della Riserva Naturale "Monte Rufeno" (Lazio): dati da borre di barbagianni Tyto alba. Hystrix. The Italian Journal of Mammalogy, 2 (1): 23-34.

Amori G., Contoli L., Nappi A. (eds.), 2008 - Mammalia II. Erinaceomorpha, Soricomorpha, Lagomorpha, Rodentia. Fauna d'Italia. Edizioni Calderini - Il Sole 24 ORE Business Media, Milano, XLIV.

Andrade A., de Menezes J. F. S. \& Monjeau A., 2016 Are owl pellets good estimators of prey abundance? Journal of King Saud University-Science, 28 (3): 239244.

Avenant N. L., 2005 - Barn owl pellets: a useful tool for monitoring small mammal communities. Belgian Journal of Zoology, 135 (suppl.): 39-43.

Balestrieri A., Gazzola A., Formenton G. \& Canova L., 2019 - Long-term impact of agricultural practices on the diversity of small mammal communities: a case study based on owl pellets. Environmental Monitoring and Assessment, 191 (725). <https://doi.org/10.1007/ s10661-019-7910-5>

Battisti C., Cignini B. \& Contoli L., 1997 - Geographical peninsular effects on the trophic system "Tyto albamicromammals" in Salento (Italy). Hystrix, the Italian Journal of Mammalogy, 9 (1-2): 13-22.
Battisti C., Dodaro G., Di Bagno E. \& Amori G., 2019 Reviewing an eco-biogeographic question at regional scale: the unexpected absence of a ubiquitous mammal species (Microtus savii, Rodentia) in coastal Southern Tuscany (central Italy). Rendiconti Lincei. Scienze Fisiche e Naturali, 30: 715-722.

Battisti C., Marta S., Agnelli P., Luiselli L., Stoch F. \& Amori G., 2020a - Peninsular effect on species richness in Italian small mammals and bats. Mammalia, 85 (3): 248-255. <https://doi.org/10.1515/mammalia2019-0122>

Battisti C., Dodaro G., Di Bagno E. \& Amori G., 2020b Small mammal assemblages in land-reclaimed areas: do historical soil use changes and recent anthropisation affect their dominance structure? Ethology Ecology \& Evolution, 32 (3): 282-288.

Biedma L., Román J., Godoy J. A. \& Calzada J., 2019 Using owl pellets to infer habitat associations and clarify the regional distribution of a cryptic shrew. Journal of Zoology, 308: 139-148.

Blasi C., 1994 - Fitoclimatologia del Lazio. Fitosociologia, 27: 151-175.

Bond G., Burnside N. G., Metcalfe D. J. \& Scott D. M., 2004 - The effect of land-use and landscape structure on Barn owl (Tyto alba) breeding success in Southern England, U.K. Landscape Ecology, 20: 555-566.

Bonvicino C. R. \& Bezerra A. M., 2003 - Use of regurgitated pellets of Barn owl (Tyto alba) for inventorying small mammals in the Cerrado of Central Brazil. Studies on Neotropical Fauna and Environment, 38 (1): $1-5$.

Brunelli M., Sarrocco S., Corbi F., Sorace A., Boano A., De Felici S., Guerrieri G., Meschini A. \& Roma S., 2011 - Nuovo Atlante degli Uccelli Nidificanti nel Lazio. Edizioni ARP (Agenzia Regionale Parchi), Roma.

Capizzi D. \& Luiselli L., 1998 - A comparative study of the variability of owl diets in three localities of central Italy. Revue d'écologie, 53: 367-385.

Caroli L., Capizzi D. \& Luiselli L., 2000 - Reproductive strategies and life-history traits of the Savi's pine vole, Microtus savii. Zoological Science, 17 (2): 209216.

Catalisano A. \& Massa B., 1987 - Considerations on the structure of the diet of the Barn owl (Tyto alba) in Sicily (Italy). Italian Journal of Zoology, 54: 69-73.

Celauro D. \& Battisti C., 2006 - Small mammal communities in a suburban agroforest landscape (Rome, Central Italy): faunal and ecological considerations using Tyto alba pellets. Aldrovandia, 2: 55-60.

Clark Jr. D. R. \& Bunck C. M., 1991 - Trends in North American small mammals found in common barn-owl (Tyto alba) dietary studies. Canadian Journal of Zoology, 69: 3093-3102.

Contoli L., 1975 - Micro-mammals and environment in central Italy: Data from Tyto alba (Scop.) pellets. Italian Journal of Zoology, 42: 223-229.

Contoli L., 1980 - Borre di Strigiforni e ricerca teriologica in Italia. Natura e Montagna, 3: 73-94.

Contoli L., 1986 - Sistemi trofici e corologia: dati su Soricidae, Talpidae ed Arvicolidae d'Italia predati da Tyto alba (Scopoli 1769). Hystrix, 1 (2): 95-118. 
Contoli L. \& Sammuri G., 1978 - Predation on small mammals by tawny owl and comparison with barn owl in the Farma valley (central Italy). Italian Journal of Zoology, 45: 323-335.

Contoli L., Salucci M. P. \& Vigna Taglianti A., 1987 - Per una biogeografia dei sistemi trofici: il sistema "mammiferi terragnoli-Tyto alba" nell'Italia peninsulare e nelle isole maggiori. Biogeographia. The Journal of Integrative Biogeography, 11: 211-231.

Contoli L., Aloise G., Amori G. \& Ranazzi L., 1992 Sull'uso dei predatori nel censimento dei micromammiferi terragnoli. Supplemento alle Ricerche di Biologia della Selvaggina, 16: 449-464.

Contoli L., Testi A., Tittarelli L. \& Benedetti P., 2002 Are animal trophic systems as reliable an expression of climate as are plant communities? Preliminary evidence from the tyrrhenian belt in Italy. Ecologia mediterranea, 28: 75-92.

Cutini M., Cancellieri L., Cioffi M. T. \& Licursi C., $2010-$ Phytosociology and phytogeography of fragmented Alnus glutinosa forests in a Tyrrhenian district (Central Italy). Ecologia Meditrranea, 36 (2): 55-73.

De Zuliani E., 2011 - Diacrhronic analysis of the Maremma laziale (Latium) for the conservation of the natural and cultural landscapes. Università degli Studi Roma Tre. $\mathrm{Ph}$. Doct. Thesys, available on: < https://arcadia. sba.uniroma3.it/handle/2307/4578>

Dytham C., 2011 - Choosing and using statistics: a biologist's guide. John Wiley \& Sons.

Farina A., 2001 - Ecologia del Paesaggio. Principi, metodi e applicazioni. UTET Libreria, Torino.

Hammer Ø., Harper D. A. T. \& Ryan P. D., 2001 - Past: Paleontological Statistics Software Package for Education and Data Analysis. Palaeontologia Electronica, 4 (1): 1-9.

Heisler L. M., Somers C. M. \& Poulin R. G., 2016 - Owl pellets: a more effective alternative to conventional trapping for broad-scale studies of small mammal communities. Methods in Ecology and Evolution, 7: 96-103.

Hill M. O. \& Gauch H. G., 1980 - Detrended correspondence analysis, an improved ordination technique. Vegetation, 42: 47-58.

Horváth A., Morvai A. \& Horváth G. F., 2018 - Foodniche pattern of the Barn Owl (Tyto alba) in intensively cultivated agricultural landscape. Ornis Hungarica, 26: 27-40.

Kiamos N., Lymberakis P., Rallis G. \& Poulakakis N., 2019 - Barn owl (Tyto alba) prey in Evros (Greece) and the discovery of a new mammal for the Greek fauna. Journal of Natural History, 53: 1691-1705.

Leveau L. M., Teta P. V., Bogdaschewsky R. \& Pardiñas U. F. J., 2006 - Feeding habits of the Barn Owl (Tyto alba) along a longitudinal-latitudinal gradient in central Argentina. Ornitologia Neotropical, 17: 353-362.

Loy A., Aloise G., Ancillotto L., Angelici F. M., Bertolino S., Capizzi D., Castiglia R., Colangelo P., Contoli L., Cozzi B., Fontaneto D., Lapini L., Maio N., Monaco A., Mori E., Nappi A., Podestà M., Russo D., Sarà M., Scandura M., Amori G., 2019 - Mammals of Italy: an annotated checklist. Hystrix, 30: 87-106.
Love R. A., Webon C., Glue D. E., Harris S. \& Harris S., 2000 - Changes in the food of British Barn Owls (Tyto alba) between 1974 and 1997. Mammal review, 30: 107-129.

Magurran A., 2004 - Measuring biological diversity. Blackwell Publishing, Malden, MA.

Mancini M. C., Roth P. R. O., Brennand P. G., Aguilar J. M. R. E. \& Rocha P. A., 2019 - Tyto furcata (Tytonidae: Strigiformes) pellets: tools to access the richness of small mammals of a poorly known Caatinga area in northeast Brazil. Mammalia, 83: 390-398.

Marchetti M., Sapia V., Garello A., De Rita D. \& Venuti A., 2014 - Geology and geophysics at the archeological park of Vulci (central Italy). Annals of Geophysics, 57 (1): G0188.

Margalef R., 1958 - Information theory in ecology. General Systems, 3: 36-71.

Martínez J. A. \& Zuberogoitia I., 2004 - Habitat preferences and causes of population decline for Barn Owls Tyto alba: a multi-scale approach. Ardeola, 51: 303317.

McDonald K., Burnett S. \& Robinson W., 2014 - Utility of owl pellets for monitoring threatened mammal communities: an Australian case study. Wildlife Research, 40: 685-697.

McDowell M. C. \& Medlin G. C., 2009 - Using the diet of the barn owl (Tyto alba) as an indicator of small vertebrate abundance in the Channel Country, southwestern Queensland. Australian Mammalogy, 31: 7580.

Meek W. R., Burman P. J., Sparks T. H., Nowakowski M. \& Burman N. J., 2012 - The use of Barn Owl Tyto alba pellets to assess population change in small mammals. Bird Study, 59: 166-174.

Milana G., Battisti C., Luiselli L. \& Amori G., 2019 Altitudinal variation of community metrics in Italian small mammal assemblages as revealed by Barn Owl (Tyto alba) pellets. Zoologischer Anzeiger, 281: 11-15.

Olmi M. \& Zapparoli M., 1992 - Ambiente nella Tuscia laziale. Aree protette e di interesse naturalistico della provincia di Viterbo. Università degli Studi della Tuscia. Union Printing Edizioni.

Pielou E. C., 1966 - The measurement of diversity in different types of biological collections. Journal of Theoretical Biology, 13: 131-144.

Prete S., Battisti C., Marini F. \& Ciucci P., 2012 - Applying abundance/biomass comparisons on a small mammal assemblage from Barn owl (Tyto alba) pellets (Mount Soratte, central Italy): a cautionary note. Rendiconti Lincei, 23 (4): 349-354.

Regione Lazio, 1990 - Technical Regional Map (scale 1:10,000). Regione Lazio, Roma.

Reidsma P., Tekelenburg T., van den Berg M. \& Alkemade R., 2006 - Impacts of land-use change on biodiversity: an assessment of agricultural biodiversity in the European Union. Agriculture Ecosystems \& Environment, 114: 86-102.

Rondinini C., Battistoni A., Peronace V. \& Teofili C. (eds.), 2013 - Lista Rossa IUCN dei Vertebrati Italiani. Comitato Italiano IUCN e Ministero dell'Ambiente e della Tutela del Territorio e del Mare, Roma. 
Salvati L., Ranazzi L. \& Manganaro A., 2002 - Habitat preferences, breeding success and diet of barn owls in Rome: urban versus rural territories. Journal of Raptor Research, 36: 224-228.

Shannon C. E. \& Weaver W., 1949 - The mathematical theory of communication. University of Illinois Press, Urbana.

Stefke K. \& Landler L., 2020 - Long-term monitoring of rodent and shrew communities in a biodiversity hotspot in Austria using Barn owl (Tyto alba) pellets. Acta Oecologica, 109: 103660.

Taberlet P. \& Fumagalli L., 1996 - Owl pellets as a source of DNA for genetic studies of small mammals. Molecular Ecology, 5: 301-305.

Taylor I. R., 1994 - Barn owls. Predator-prey Relationships and Conservation. Cambridge University Press, Cambridge, UK.

Tome R. \& Valkama J., 2001 - Seasonal variation in the abundance and habitat use of Barn Owls (Tyto alba) on lowland farmland. Ornis Fennica, 78: 109-118.

Torre I., Gracia-Quintas L., Arrizabalaga A., Baucells J. \& Díaz M., 2015 - Are recent changes in the terrestrial small mammal communities related to land use change? A test using pellet analyses. Ecological Research, 30: 813-819.

Varuzza P., Capizzi D., Santini L. \& Apollonio M., 2001 Barn Owl Tyto alba predation on small mammals in relation to the Mediterranean environment (Pisa Province, Italy). Acta Ornithologica, 36 (2): 153-160.

Veselovský T., Bacsa K. \& Tulis F., 2017 - Barn Owl (Tyto alba) diet composition on intensively used agricultural land in the Danube Lowland. Acta Universitatis Agriculturae et Silviculturae Mendelianae Brunensis, 65: 225-233.

Yom-Tov Y. \& Wool D., 1997 - Do the contents of Barn Owl pellets accurately represent the proportion of prey species in the field? The Condor, 99 (4): 972-976. 